\title{
Global and regional longitudinal function recovery in patients with severe aortic stenosis after aortic valve replacement
}

\section{Vlatka Rešković Lukšić* \\ Dejan Došen \\ Sanja Ceković \\ Sandra Večerić \\ Jadranka Šeparović \\ Hanževački}

University of Zagreb Schoo of Medicine, University Hospital Centre Zagreb

Zagreb, Croatia
KEYWORDS: echocardiography, speckle tracking, longitudinal deformation, aortic stenosis, aortic valve replacement. CITATION: Cardiol Croat. 2015;10(3-4):65. | DOI: http://dx.doi.org/10.15836/ccar.2015.65

ORCID: Vlatka Rešković Lukšić, http://orcid.org/0000-0002-4721-3236 • Dejan Došen, http://orcid.org/0000-0002-2641-4768 - Sanja Ceković, http://orcid.org/0000-0003-3892-7680 • Sandra Večerić, http://orcid.org/0000-0002-8070-1012 • Jadranka Šeparović Hanževački, http://orcid.org/0000-0002-3437-6407

*ADDRESS FOR CORRESPONDENCE: Vlatka Rešković Lukšić, Klinički bolnički centar Zagreb, Kišpatićeva 12, HR-10000 Zagreb, Croatia. Phone: +385-91-561-2526. E-mail: vlatka.reskovic@gmail.com

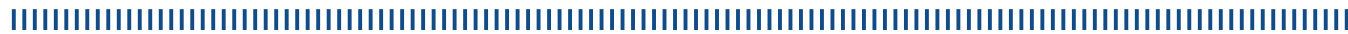

AIM: Global and regional left ventricular (LV) longitudinal strain (LS) is often reduced, despite normal LV ejection fraction (LVEF) in patients with severe aortic stenosis (AS) ${ }^{1-4}$ We wanted to analyze subtle regional longitudinal LV deformation changes after aortic valve replacement (AVR).

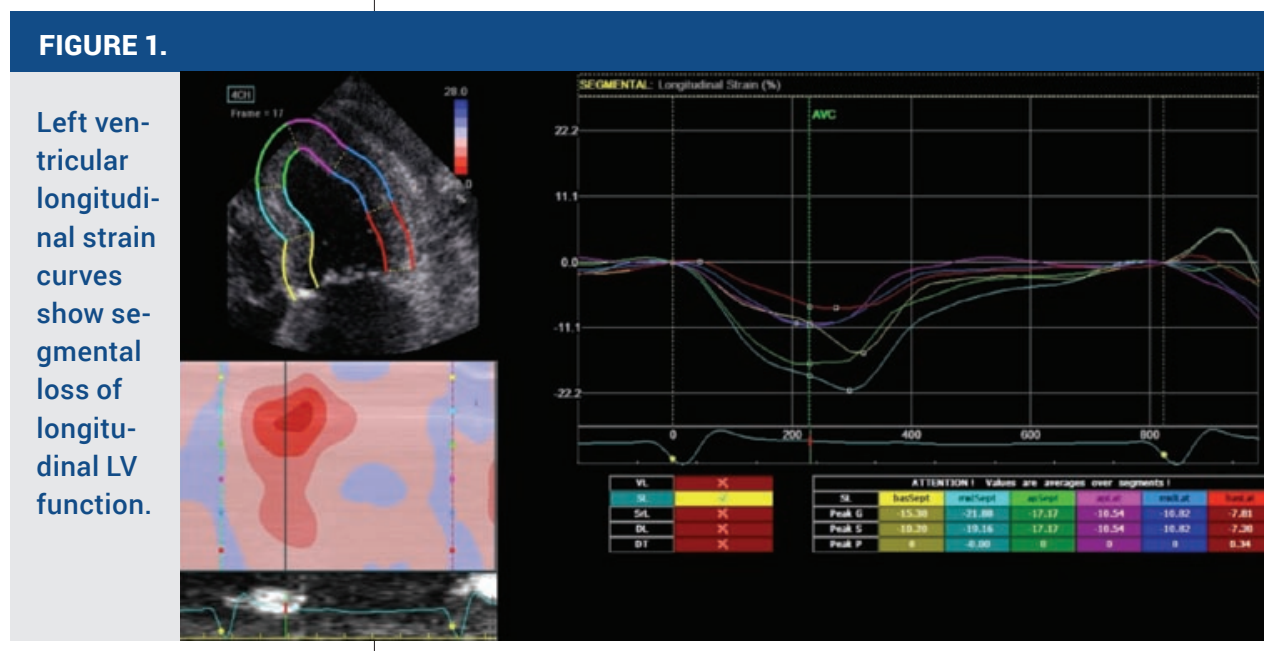

PATIENTS AND METHODS: 45 patients with severe symptomatic AS (AVA/BSA $\left.0.33 \pm 0.09 \mathrm{~cm}^{2} / \mathrm{m}^{2}\right)$ and preserved LVEF (57.3\% \pm 8$)$, without concomitant coronary artery disease were enrolled. Complete transthoracic echocardiography with longitudinal strain analysis by speckle tracking was performed before, in early postoperative period $(7.5 \pm 6.2$ postoperative days) and late follow up (mean 17.14 months).

RESULTS: GLS was reduced in patients prior AVR (-12.64 $\pm 6.7 \%)$ (Figure 1) We found no statistically significant difference in GLS ( $p=0.888)$ in early postoperative period and neither in late follow up ( $\mathrm{p}=0.109)$, although trend was towards improvement in global LS and absolute values came close to normal (-19.6\%). Regional longitudinal strain analysis of the LV basal segments in early postoperative period showed significant improvement of longitudinal LV function in the basal interventricular (IV) septum ( $\mathrm{p}=0.011)$. Those differences were even more expressed in late follow up - there was also significant improvement of LS in the basal lateral LV wall ( $\mathrm{p}=0.015)$.

\section{RECEIVED:}

April 15, 2015

ACCEPTED:

April 20, 2015

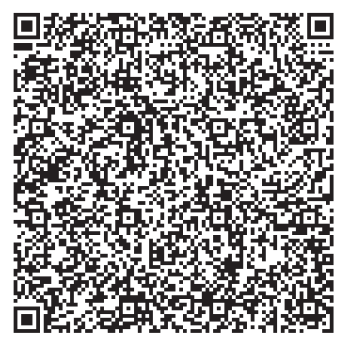

CONCLUSION: After AVR, even in early postoperative period, we found significant improvement of longitudinal deformation in basal IV septum. Those changes attribute to pressure unload, while in late follow up, because of LV positive remodeling, basal lateral LV segment also recovers in longitudinal function. We conclude that IV septum has not permanently lost his longitudinal function in spite of low longitudinal LS prior surgery. This is the area most prone to pressure overload state and it recovers immediately after operation due to pressure unload. Later on positive remodeling takes place, so that other LV segments can also improve their function.

LITERATURE IIIIIIIIIIIIIIIIIIIIIIIIIIIIIIIIIIIIIIIIIIIIIIIIIIIIIIIIIIIIIIIIIIIIIIIIIIIIIIIIIIIIIIIIIIIIIIIII

1. Delgado V, Tops LF, van Bommel RJ, van der Kley F, Marsan NA, Klautz RJ, et al. Strain analysis in patients with severe aortic stenosis and preserved left ventricular ejection fraction undergoing surgical valve replacement. Eur Heart J. 2009;30(24):3037-47. DOI: http://dx.doi.org/10.1093/eurheartj/ehp351

2. Rešković Lukšić V, Došen D, Večerić S, Pašalić M, Šeparović Hanževački J. Early regional myocardial deformation and function changes in patients with severe aortic stenosis after aortic valve replacement. Cardiol Croat. 2014;9(9-10):383. DOI: http://dx.doi.org/10.15836/ccar.2014.383

3. Delgado V, Tops LF, van Bommel RJ, van der Kley F, Klautz RJ, Holman ER, et al. Changes in left ventricular myocardial strain after aortic valve replacement: comprehensive 2-dimensional speckle tracking strain imaging assessment. Circulation. 2008;118:S_933.

4. Gelsomino S, Lucà F, Parise 0 , Lorusso R, Rao CM, Vizzardi E, et al. Longitudinal strain predicts left ventricular mass regression after aortic valve replacement for severe aortic stenosis and preserved left ventricular function. Heart Vessels. 2013;28(6):775-84. DOI: http://dx.doi.org/10.1007/s00380-012-0308-8
Cardiologia Croatica 2015;10(3-4):65 